\title{
PENENTUAN KATEGORI KONSENTRASI BERBAGAI PEUBAH KIMIA KUALITAS TANAH PADA KEDALAMAN BERBEDA DI TAMBAK PROVINSI SULAWESI SELATAN, INDONESIA
}

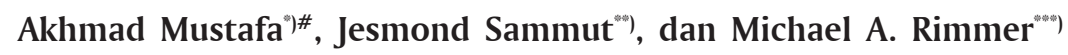 \\ ") Balai Penelitian dan Pengembangan Budidaya Air Payau \\ ") The University of New South Wales, Sydney, Australia \\ The University of Sydney, Sydney, Australia
}

(Naskah diterima: 4 September 2015; Revisi final: 2 November 2015; Disetujui publikasi: 9 November 2015)

\begin{abstract}
ABSTRAK
Kualitas tanah adalah salah satu faktor penentu keberhasilan dan keberlanjutan usaha budidaya tambak, termasuk budidaya tambak di Provinsi Sulawesi Selatan, Indonesia. Namun demikian, sampai saat ini belum ada data mengenai kategori konsentrasi peubah kimia kualitas tanah untuk tanah tambak di Indonesia. Studi ini bertujuan untuk menentukan kategori konsentrasi peubah kimia kualitas tanah sebagai langkah awal dalam menginterpretasi kualitas tanah tambak di Sulawesi Selatan secara khusus dan di Indonesia secara umum. Contoh tanah diambil pada 1.196 titik pengambilan dengan masing-masing dua kedalaman tanah yang tersebar di 13 kabupaten di Sulawesi Selatan. Sebanyak 18 peubah kimia kualitas tanah telah diukur langsung di lapangan atau dianalisis di laboratorium. Uji t digunakan untuk mengetahui perbedaan kualitas tanah pada kedalaman yang berbeda. Konsentrasi setiap peubah kimia kualitas tanah disusun dari terkecil ke terbesar kemudian dilakukan penentuan letak desil dan nilai desil sebagai dasar dalam penentuan kategori konsentrasi setiap peubah kimia kualitas tanah. Hasil studi menunjukkan bahwa secara umum tanah tambak di Sulawesi Selatan pada kedalaman 0-0,2 m memiliki kemasaman dan unsur toksin (Fe, Al) yang lebih rendah dan sebaliknya konsentrasi unsur hara makro $(\mathrm{N}, \mathrm{P})$ yang lebih tinggi dibandingkan pada kedalaman 0,2-0,5 m. Peubah kualitas tanah lainnya seperti $\mathrm{S}_{\mathrm{KCl}}, \mathrm{S}_{\mathrm{P}}$, dan $\mathrm{S}_{\mathrm{POS}}$ relatif sama pada kedua kedalaman. Data setiap peubah kualitas tanah telah disusun ke dalam kategori konsentrasi (sangat rendah, rendah, sedang, tinggi, sangat tinggi) untuk memfasilitasi perbandingan dengan data lain mengenai kualitas tanah untuk budidaya tambak. Hasil studi ini tidak disarankan untuk digunakan dalam menentukan hubungan antara kualitas tanah dan produktivitas tambak, tetapi dapat menjadi dasar dalam menentukan peubah kimia kualitas tanah tambak termasuk kategori sangat rendah, rendah, sedang, tinggi, atau sangat tinggi dan membuat keputusan untuk perbaikan kualitas tanah.
\end{abstract}

KATA KUNCI: $\quad$ kategori konsentrasi, kimia, tanah, tambak, Sulawesi Selatan

ABSTRACT: Determination of concentration categories of various soil quality chemical variables in different depths in brackishwater ponds of South Sulawesi Province, Indonesia. By: Akhmad Mustafa, Jesmond Sammut, and Michael A. Rimmer

Soil quality is one of the determining factors in the success and sustainability of brackishwater ponds, including brackishwater ponds in South Sulawesi Province, Indonesia. Nevertheless, up until now there have not yet been any data regarding the concentration categories of soil quality chemical variables for brackishwater ponds soil in Indonesia. This study was conducted with a purpose to determine the concentration categories of soil quality chemical variables as the first step in interpreting the soil quality of brackishwater ponds particularly in South Sulawesi and generally in Indonesia. Soil samples were taken at 1,196 sampling points, each of which was with two depths of soil. All of those sampling points were spread in 13 regencies in South Sulawesi. As many as 18 soil quality chemical variables were measured directly in the field or analyzed in the laboratory. $t$ test was used to find out the difference of soil qualities in different depths. Concentrations of soil quality chemical variables were arranged from the smallest to the largest and then decile location and decile value were determined as a basis in determining the concentration category of each soil

\# Korespondensi: Balai Penelitian dan Pengembangan

Budidaya Air Payau. Jl. Makmur Dg. Sitakka No. 129, Maros

90512, Sulawesi Selatan, Indonesia. Tel.: + (0411) 371544

E-mail: akhmadmustafa@yahoo.com 
quality chemical variable. The results of study show that generally brackishwater ponds soil in South Sulawesi with the depth 0-0.2 $m$ have lower acidity and toxic element (Fe, Al) and on the contrary the soil have higher macro nutrient element $(N, P)$ compared to that in depth 0.2-0.5 m. Other soil quality variables such as $S_{K C P}, S_{P}$, and $S_{P O S}$ are relatively the same in both soil depths. The data of each soil quality variable have been arranged into concentration categories (very low, low, medium, high, very high) to facilitate comparisons with other data regarding soil quality for brackishwater ponds. The results of this study are not recommended to be used in determining the relationship between soil quality and brackishwater ponds productivity, but they can become a basis in determining the soil quality chemical variables of brackishwater ponds including the categories of very low, low, medium, high, or very high and make decisions to improve soil quality.

\section{KEYWORDS: $\quad$ concentration category, chemical, soil, brackishwater pond, South Sulawesi}

\section{PENDAHULUAN}

Kementerian Kelautan dan Perikanan (KKP) Republik Indonesia telah memfokuskan untuk meningkatkan produksi perikanan budidaya atau akuakultur melalui program Minapolitan dan Industrialisasi berbasis Ekonomi Biru. Akuakultur yang dilakukan di Indonesia meliputi: budidaya air payau (tambak), budidaya air tawar (kolam), budidaya laut (marikultur), perairan umum, dan mina padi (KKP, 2014). Di antara jenis akuakultur tersebut, budidaya tambak merupakan industri akuakultur terbesar di Indonesia.

Sulawesi Selatan merupakan provinsi yang tambaknya tergolong luas di Indonesia yaitu mencapai 105.859 ha dari luas total 682.857 ha. Tambak di Sulawesi Selatan tersebar di 18 kabupaten/kota dari 24 kabupaten/kota dan digunakan untuk budidaya udang windu (Penaeus monodon), udang putih (Penaeus merguienis), udang vaname (Litopenaeus vannamei), udang apiapi (Metapenaeus monoceros), kepiting bakau (Scylla sp.), ikan bandeng (Chanos chanos), ikan nila (Oreochromis niloticus), ikan mujair (Tilapia mosambica), ikan betok (Anabas testudineus), ikan kakap (Lates calcarifer), ikan baronang (Siganus guttatus), ikan mas (Cyprinus carpio), ikan gurami (Osphronemus goramy), ikan patin (Pangasius djambal), dan atau rumput laut (Gracilaria verrucosa), baik secara monokultur maupun polikultur (DKP, 2013).

Tambak di Indonesia termasuk di Sulawesi Selatan umumnya dibangun di lahan rawa. Lahan rawa adalah lahan yang masih dipengaruhi oleh pasang surut atau aliran sungai sekitarnya. Ada tiga jenis tanah yang dijumpai di lahan rawa yaitu: tanah sulfat masam, tanah gambut, dan tanah nonsulfat masam termasuk tanah salin. Dengan demikian, kualitas tanah tambak di Sulawesi Selatan dapat dijadikan gambaran umum tanah tambak di Indonesia.

Kualitas tanah adalah faktor penentu dominan dalam budidaya tambak sehingga dipertimbangkan sebagai kriteria dalam kesesuaian lahan untuk budidaya tambak (Boyd, 1995; Salam et al., 2003; Giap et al., 2005; Karthik et al., 2005; Mustafa et al., 2007; Hardjowigeno \& Widiatmaka, 2011; Mustafa, 2012). Tanah adalah faktor produksi utama dalam budidaya tambak, karena memengaruhi kualitas air, proses biologis, dan rekayasa tambak (Boyd, 1989; Sammut, 1999), mengontrol kestabilan dasar tambak, pH air, dan konsentrasi unsur hara yang dibutuhkan untuk makanan alami (Ekubo \& Abowei, 2011; Caipang et al., 2012; Siddique et al., 2012), serta menjaga keseimbangan dalam ekosistem tambak (Ahmed, 2004). Kualitas tanah dasar tambak dan proses yang terjadi pada tanah dasar tambak, serta hubungan tanah dan air tambak menjadi sangat penting bagi pertumbuhan ikan atau udang (Avnimelech \& Ritvo, 2003; Ndome et al., 2012). Dalam upaya untuk memiliki pemahaman yang jelas tentang berbagai proses kimia, fisika, dan biologis tanah dan untuk membuat keputusan tentang kesesuaian lahan untuk budidaya tambak, serta pengelolaan yang efektif dari tanah untuk meningkatkan produktivitas tambak, maka diperlukan pengetahuan yang baik terhadap kualitas tanah. Proses kimia, fisika, dan biologis tanah tambak dapat memengaruhi kualitas air dan banyak masalah kualitas air diakibatkan oleh kualitas tanah (Boyd, 1992).

Permukaan tanah dasar tambak adalah bagian yang paling besar pengaruhnya terhadap kondisi lingkungan tambak lainnya seperti kualitas air. Meskipun pengelolaan kualitas air dianggap salah satu faktor budidaya paling penting, tetapi banyak bukti bahwa kondisi dasar tambak dan pertukaran substansi antara tanah dan air sangat berpengaruh terhadap kualitas air (Boyd, 1995; Siddique et al., 2012). Telah dibuktikan bahwa kontak langsung udang windu dengan tanah dasar melalui aqueous phase merupakan salah satu penyebab rendahnya sintasan udang windu di tambak tanah sulfat masam (Mustafa, 2007). Akan tetapi karakteristik tanah pada tanah yang lebih dalam perlu diketahui, mengingat bahwa dalam pembuatan tambak atau pun dalam pengelolaan tambak harus dilakukan penggalian tanah permukaan agar kedalaman air yang sesuai untuk budidaya tambak dapat dipenuhi atau untuk mendapatkan permukaan tanah baru yang berbeda kualitasnya. Karakteristik tanah tambak dapat bervariasi dengan adanya perbedaan kedalaman tanah (Boyd, 1976; Mustafa et al., 2011). 
Analisis tanah merupakan alat dalam pengelolaan akuakultur yang belum banyak dikembangkan. Data kualitas tanah tambak jarang digunakan oleh pembudidaya tambak, tetapi kualitas tanah yang rendah sering dicurigai oleh pembudidaya tambak apabila tidak dapat menjelaskan pertumbuhan yang lambat atau sintasan yang rendah dari organisme akuatik sebagai akibat serangan penyakit, kualitas pakan yang rendah, kondisi cuaca yang ekstrem, kualitas air yang buruk, pengelolaan yang tidak tepat, atau penyebab umum lainnya. Karakteristik tanah tambak dalam hubungannya dengan kesesuaian lahan di Indonesia telah banyak dilaporkan sebelumnya (Mustafa et al., 2011; Utojo et al., 2010, 2011, 2012, 2013; Hasnawi \& Mustafa, 2010; Rachmansyah et al., 2010, 2012; Rachmansyah \& Mustafa, 2011b). Kategori konsentrasi peubah kualitas tanah tambak di Indonesia belum ditentukan, walaupun Mustafa et al. (2008b), Mustafa (2009; 2010), Mustafa \& Sammut (2010), dan Mustafa \& Ratnawati (2013) telah membuat beberapa hubungan antara kualitas tanah dan produktivitas tambak. Kategori konsentrasi tanah tambak di Thailand, Filipina, Ekuador, dan Venezuela telah dilaporkan oleh Boyd et al. (1994). Di Indonesia, kategori konsentrasi tanah pertanian secara umum telah dilaporkan oleh Pusat Penelitian Tanah (1993) dalam Hardjowigeno \& Widiatmaka (2011). Studi ini dilakukan untuk mendapatkan informasi mengenai kategori konsentrasi peubah kimia kualitas tanah pada dua kedalaman berbeda di tambak Sulawesi Selatan.

\section{BAHAN DAN METODE}

\section{Pengambilan Contoh Tanah}

Contoh tanah diambil dari tambak yang berlokasi di Kabupaten Pinrang, Barru, Pangkep, Maros, Takalar, Bulukumba, Kepulauan Selayar, Sinjai, Bone, Wajo, Luwu, Luwu Utara, dan Luwu Timur, Provinsi Sulawesi Selatan, Indonesia (Gambar 1). Contoh tanah diambil dengan menggunakan bor tanah berdiameter $5 \mathrm{~cm}$.

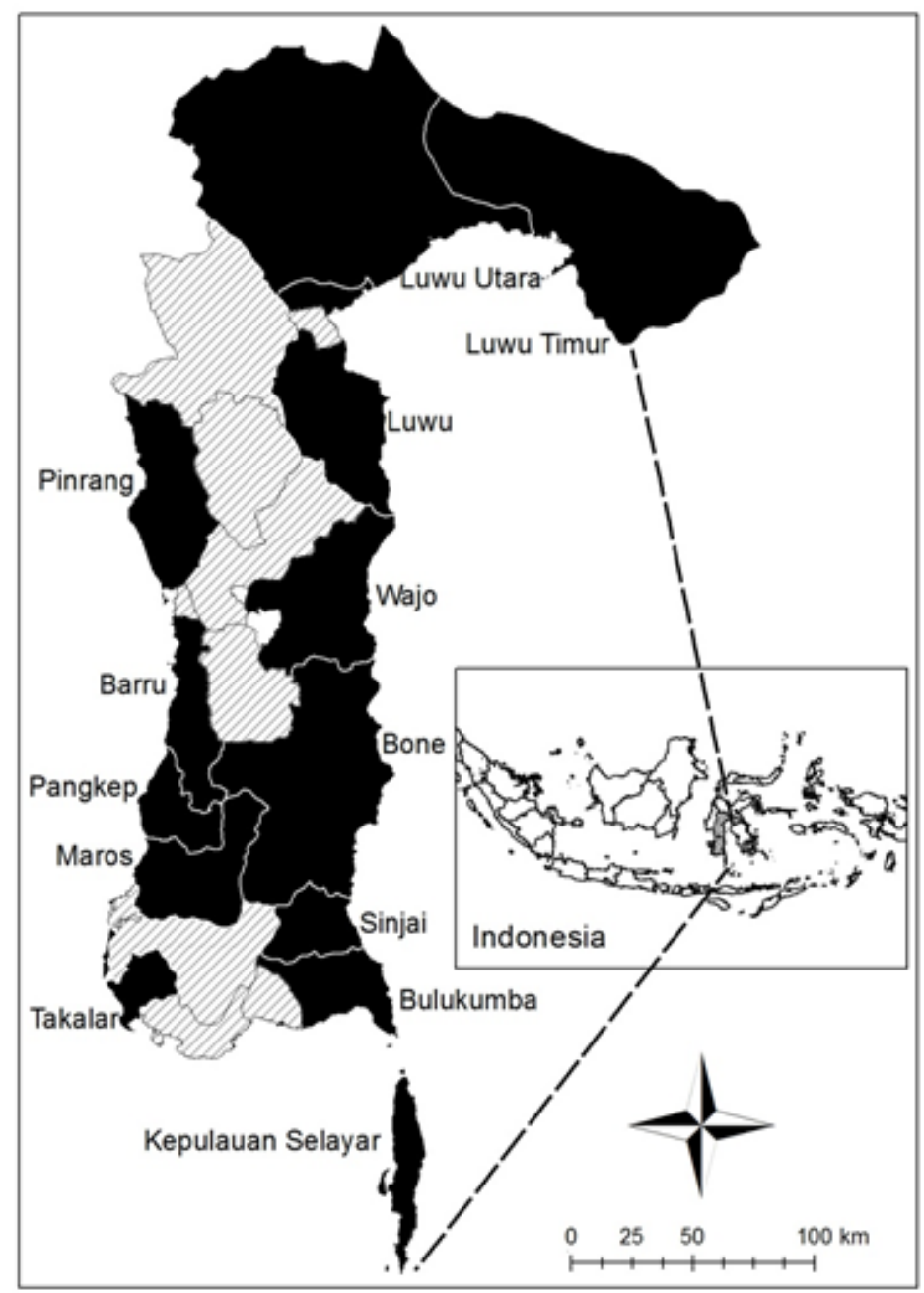

Gambar 1. Lokasi studi di tambak yang tersebar di 13 kabupaten di Provinsi Sulawesi Selatan, Indonesia

Figure 1. Study locations in brackishwater ponds distributed in 13 regencies in South Sulawesi Province, Indonesia 
Jumlah titik pengambilan contoh tanah adalah 1.196 titik yang tersebar di 13 kabupaten tersebut, di mana penentuan titik pengambilan contoh didasarkan pada petunjuk Rayes (2007).

Contoh tanah pada satu petak tambak diambil pada dua tempat yaitu pada pelataran dan saluran keliling tambak yang selanjutnya dikomposit untuk mewakili satu titik pengambilan contoh tanah. Contoh tanah pada satu titik pengambilan contoh tanah diambil pada dua kedalaman tanah yaitu 0-0,2 dan 0,2-0,5 m. Pada saat pengukuran dan pengambilan contoh tanah, umumnya tambak terisi air sebab sedang digunakan untuk budidaya udang windu atau ikan bandeng atau ikan nila atau polikultur udang windu dan ikan bandeng atau polikultur ikan bandeng dan rumput laut. Setelah sisa tumbuhan segar, kerikil, cangkang, dan kotoran lainnya dibuang dan bongkahan besar dikecilkan dengan tangan, contoh tanah tersebut dimasukkan dalam kantong plastik dan disimpan dalam cold box yang diberi es (Ahern et al., 2004) dan selanjutnya dibawa ke laboratorium.

\section{Analisis Tanah}

Peubah kualitas tanah yang diukur langsung di lapangan adalah $\mathrm{pH}_{\mathrm{F}}(\mathrm{pH}$ tanah diukur langsung dengan menggunakan pH-meter) (Ahern \& Rayment, 1998) dan $\mathrm{pH}_{\mathrm{FOX}}(\mathrm{pH}$ tanah setelah dioksidasi dengan hidrogen peroksida $\left(\mathrm{H}_{2} \mathrm{O}_{2}\right) 30 \%$ kemudian diukur dengan menggunakan pH-meter (Ahern \& Rayment, 1998; Hazelton \& Murphy, 2009). Untuk analisis peubah kualitas tanah lainnya, maka contoh tanah diovenkan pada suhu $80^{\circ} \mathrm{C}-85^{\circ} \mathrm{C}$ selama 48 jam untuk contoh tanah yang tergolong tanah sulfat masam dan tanah gambut (Ahern \& Blunden, 1998) dan dikeringanginkan pada rak di ruang khusus bebas kontaminan yang terlindung dari sinar matahari untuk contoh tanah yang tergolong tanah non-sulfat masam (Sulaeman et al., 2005; Eviati \& Sulaeman, 2009). Setelah kering, tanah dihaluskan dengan cara ditumbuk pada lumpang porselin dan diayak dengan ayakan ukuran lubang 2,0 $\mathrm{mm}$. Untuk mendapatkan contoh ukuran partikel lebih kecil dari 0,5 mm; maka contoh ukuran partikel lebih kecil dari 2,0 mm ditumbuk dan diayak dengan ayakan ukuran lubang $0,5 \mathrm{~mm}$. Contoh tanah dianalisis di Laboratorium Tanah Balai Penelitian dan Pengembangan Budidaya Air Payau di Maros, Provinsi Sulawesi Selatan.

Peubah kualitas tanah yang dianalisis di laboratorium adalah peubah khas tanah sulfat masam, sebab sebagian besar contoh tanah tergolong tanah sulfat masam. Kualitas tanah yang dianalisis di laboratorium meliputi $\mathrm{pH}_{\mathrm{KCl}}(\mathrm{pH}$ dari ekstrak $\mathrm{KCl})$ (McElnea \& Ahern, 2004a), $\mathrm{pH}_{\mathrm{ox}}$ (pH dari ekstrak $\mathrm{H}_{2} \mathrm{O}_{2}$ $30 \%$ ) (McElnea \& Ahern, 2004b), $S_{\mathrm{p}}$ (sulfur yang diekstrak $\mathrm{H}_{2} \mathrm{O}_{2} 30 \%$ ) (Melville, 1993; McElnea \& Ahern, 2004c), $S_{\mathrm{KCl}}$ (sulfur yang diekstrak dengan $\mathrm{KCl}$ ) (Melville, 1993; McElnea \& Ahern, 2004d), $S_{\mathrm{POS}}\left(\mathrm{S}_{\mathrm{P}}-\mathrm{S}_{\mathrm{KCI}}\right)$ (Ahern \& McElnea, 2004), TPA (Titratable Peroxide Acidity atau sebelumnya dikenal dengan Total Potential Acidity) (McElnea \& Ahern, 2004b), TAA (Titratable Actual Acidity atau sebelumnya dikenal dengan Total Actual Acidity) (McElnea \& Ahern, 2004a), TSA (Titratable Sulfidic Acidity atau sebelumnya dikenal dengan Total Sulfidic Acidity) (TPA-TAA) (McElnea \& Ahern, 2004b), pirit (Ahern et al., 1998a; 1998b), C organik dengan metode Walkley dan Black (Sulaeman et al., 2005; Eviati \& Sulaeman, 2009), $\mathrm{N}$ total dengan metode Kjedhal (Sulaeman et al., 2005; Eviati \& Sulaeman, 2009), $\mathrm{PO}_{4}$ dengan metode Bray 1 atau Olsen (Sulaeman et al., 2005; Eviati \& Sulaeman, 2009), Fe dengan spektrofotometer GENESYS 10S UV-Vis (Menon, 1973), dan Al dengan spektrofotometer GENESYS 10S UV-Vis (Menon, 1973).

Kontrol kualitas yang diaplikasikan berupa penetapan duplo pada peubah kualitas dan contoh tanah tertentu. Tanah dianalisis ulang pada peubah kualitas dan contoh tanah tertentu tersebut apabila hasil penetapan duplo berbeda lebih besar dari $10 \%$.

\section{Analisis Data}

Sebagian data yang diperoleh ini telah dianalisis lain dan telah dilaporkan sebelumnya. Data dari Kabupaten Pinrang telah dilaporkan oleh Mustafa et al. (2008a); Kabupaten Barru oleh Tarunamulia \& Mustafa (2009); Kabupaten Bulukumba oleh Utojo et al. (2009); Kabupaten Bone oleh Utojo et al. (2010); Kabupaten Luwu Utara oleh Hasnawi \& Mustafa (2010), dan Kabupaten Pangkep oleh Rachmansyah \& Mustafa (2011a) dan Mustafa \& Ratnawati (2012).

Data pencilan (outlier) setiap peubah kualitas tanah dideteksi dengan standard score atau Z-Score. Nilai-nilai kuantitatif peubah kualitas tanah pada kedalaman berbeda ditampilkan dalam bentuk rata-rata + deviasi standar. Uji Levene digunakan untuk menguji kesamaan keragaman dua populasi (kedalaman 0-0,2 dan 0,2-0,5 $\mathrm{m})$. Jika keragaman dua polulasi berbeda nyata, maka untuk membandingkan rata-rata digunakan Uji t untuk dua contoh bebas dengan asumsi keragaman tidak sama. Jika keragaman dua populasi sama, maka untuk membandingkan rata-rata digunakan Uji t untuk dua contoh bebas dengan asumsi keragaman sama. Tingkat signifikansi ditetapkan pada taraf 5\%. Konsentrasi setiap peubah kualitas tanah disusun dari terkecil ke terbesar kemudian dilakukan penentuan letak desil dan nilai desil. Nilai masing-masing peubah kualitas tanah ditentukan pada lima kategori konsentrasi sebagai berikut: desil ke-1 (sangat rendah); desil ke-2 dan desil ke-3 (rendah); desil ke-4 sampai 
desil ke-7 (sedang); desil ke-8 dan ke-9 (tinggi), dan desil ke-10 (sangat tinggi). Data dianalisis dengan menggunakan bantuan program IBM (International Business Machines) SPSS (Statistical Product and Service Solution) Statistics 20.

\section{HASIL DAN BAHASAN}

Jenis tanah yang dijumpai di tambak Sulawesi Selatan, Indonesia tergolong tanah sulfat masam, tanah gambut, dan tanah nonsulfat masam seperti telah disebutkan sebelumnya. Tanah sulfat masam yang berasosiasi dengan tanah gambut, umumnya dijumpai di pantai Timur Sulawesi Selatan seperti di Kabupaten Sinjai, Bone, Wajo, Luwu, Lutra, dan Lutim, serta Kota Palopo. Tanah sulfat masam dalam luasan yang sempit juga dijumpai di pantai Barat dan Selatan, Sulawesi Selatan. Tanah non-sulfat masam dapat dijumpai di pantai Barat dan terutama di pantai Selatan, Sulawesi Selatan.

Derajat kemasaman atau $\mathrm{pH}$ tanah merupakan salah satu peubah kualitas tanah yang sangat penting dalam mengendalikan produktivitas tambak, sebab dapat mengontrol reaksi kimia dalam lingkungan tambak. Pada tanah sulfat masam, berbagai bentuk $\mathrm{pH}$ yang sering diukur adalah $\mathrm{pH}_{\mathrm{F}}, \mathrm{pH}_{\mathrm{FOx}}, \mathrm{pH}_{\mathrm{KCl}}$, dan $\mathrm{pH}_{\mathrm{Ox}}$. Pengukuran kemasaman tanah harus dilaksanakan dalam kondisi contoh basah untuk mencegah oksidasi pirit menjadi asam sulfat yang dapat menyebabkan penurunan nilai $\mathrm{pH}$ yang besar dibandingkan dengan yang normal jika diukur secara in situ (English et al., 1997). Dari keempat bentuk pH tanah tersebut menunjukkan nilai yang lebih tinggi dan berbeda nyata $(\mathrm{P}<0,05)$ pada kedalaman tanah $0-0,2 \mathrm{~m}$ dibandingkan dengan kedalaman 0,2-0,5 m; sedangkan $\mathrm{pH}_{\mathrm{F}}-\mathrm{pH}_{\mathrm{FOX}}$ yang dapat digunakan untuk memprediksi potensi kemasaman tanah menunjukkan nilai yang lebih rendah dan berbeda nyata $(\mathrm{P}<0,05)$ pada kedalaman $0-0,2 \mathrm{~m}$ dibandingkan dengan kedalaman 0,2-0,5 m (Tabel 1). Hal ini disebabkan oleh proses remediasi tanah dasar yang menyebabkan senyawa atau unsur penyebab kemasaman lebih banyak terbuang pada permukaan tanah dasar tambak. Penyebab lain adalah pengapuran yang dilakukan oleh pembudidaya tambak pada saat persiapan tambak maupun pada saat pelaksanaan budidaya. Telah dilaporkan bahwa pembudidaya tambak mengaplikasikan kapur rata-rata $112 \mathrm{~kg} / \mathrm{ha} / \mathrm{musim} \mathrm{di}$ Kabupaten Pinrang (Mustafa \& Ratnawati, 2007), 4 kg/ ha/musim di Kabupaten Pangkep (Mustafa et al., 2010), 26 kg/ha/musim di Kabupaten Bulukumba (Ratnawati et al., 2009), $104 \mathrm{~kg} / \mathrm{ha} / \mathrm{musim}$ di Kabupaten Luwu (Mustafa \& Sammut, 2010), dan $83 \mathrm{~kg} / \mathrm{ha} /$ musim di Luwu Utara (Ratnawati et al., 2008). Namun demikian pengaruh pengapuran tersebut diduga tidak mencapai kedalaman $0,2 \mathrm{~m}$; sehingga tidak memengaruhi $\mathrm{pH}$ tanah pada kedalaman 0,2-0,5 m. Telah disebutkan sebelumnya bahwa kapur yang diberikan hanya memberikan pengaruh yang nyata sampai kedalaman tanah 0,04 m (Queiroz et al., 2004) dan 0,05 m (Conyers et al., 2003).

Nilai $\mathrm{pH}_{\mathrm{F}}, \mathrm{pH}_{\mathrm{FOX}}, \mathrm{pH}_{\mathrm{F}}-\mathrm{pH}_{\mathrm{FOX}}, \mathrm{pH}_{\mathrm{KCl}}$, dan $\mathrm{pH}_{\mathrm{OX}}$ dikategorikan sedang untuk kedalaman 0-0,2 m berturut-turut $6,70-7,20 ; 1,65-4,80 ; 2,10-5,25 ; 6,10$ 7,20; dan 1,90-4,35 (Tabel 2). $\mathrm{pH}_{\mathrm{KCl}}$ kategori sedang yang didapatkan ini relatif sama dengan yang telah dilaporkan oleh Boyd et al. (1994) untuk tambak di Thailand, Filipina, Ekuador, dan Venezuela yaitu bernilai 6,0-7,0 pada kedalaman 0-0,05 m. Khusus untuk pH, kategori bentuk lain yaitu kategori netral pada nilai pH 6,6-7,5 (Pusat Penelitian Tanah, 1993 dalam Hardjowigeno \& Widiatmaka, 2011) dan pada nilai $\mathrm{pH}$ 6,6-7,3 (Hazelton \& Murphy, 2009).

Pirit merupakan ciri khas tanah sulfat masam, salah satu sumber kemasamannya adalah sulfur. Pirit yang teroksidasi akan menghasilkan asam sulfat dan ferrosulfat yang apabila bereaksi dengan air melepaskan ferrisulfat yang selanjutnya apabila teroksidasi kembali akan menghasilkan asam sulfat. Hasil analisis sulfur $\left(\mathrm{S}_{\mathrm{KCl}}, \mathrm{S}_{\mathrm{P}}, \mathrm{S}_{\mathrm{POS}}\right)$ yang diekstrak dengan pengekstrak yang berbeda menunjukkan bahwa konsentrasi sulfur yang relatif sama pada kedua kedalaman (Tabel 1). Sebagai sumber kemasaman yang penting pada tanah sulfat masam, maka sulfur yang diukur dalam bentuk $\mathrm{S}_{\text {POS }}$ tanah telah digunakan oleh Ahern et al. (1998b) untuk menentukan kebutuhan kapur bagi tanah sulfat masam.

Hasil pengukuran peubah kualitas tanah lain yang menggambarkan kemasaman tanah yaitu TPA, TAA, dan TSA menunjukkan kecenderungan pola yang sama dengan berbagai bentuk pH. Nilai TPA, TAA, dan TSA pada kedalaman 0-0,2 m lebih rendah dan berbeda nyata $(\mathrm{P}<0,05)$ dibandingkan dengan kedalaman 0,2 0,5 m. Telah dikatakan oleh McElnea et al. (2004a; 2004b) bahwa pada tanah sulfat masam yang rendah konsentrasi bahan organiknya, maka TSA berkorelasi baik dengan $\mathrm{S}_{\mathrm{POS}}$. TSA juga mempunyai hubungan secara linear dengan konsentrasi pirit (Noor, 2004) pada tanah sulfat masam. Oleh karena itu, dari Tabel 1 terlihat bahwa konsentrasi pirit yang lebih rendah dijumpai pada kedalaman 0-0,2 m dan berbeda nyata $(\mathrm{P}<0,05)$ dengan kedalaman 0,2-0,5 m. Pada tanah sulfat masam aktual di Kalimantan didapatkan konsentrasi pirit 0,85\%-1,07\%; baik pada lapisan atas maupun lapisan bawah tanah (Subagyo, 2006). Konsentrasi pirit 0,0670\%-1,7590\% tergolong kategori sedang pada tanah tambak di Sulawesi Selatan. Belum ditemukan informasi yang melaporkan kategori konsentrasi untuk peubah $\mathrm{S}_{\mathrm{KCl}}, \mathrm{S}_{\mathrm{P}}, \mathrm{S}_{\mathrm{POS}}$, TPA, TAA, dan TSA maupun pirit tanah. 
Tabel 1. Statistik deskriptif setiap peubah kimia kualitas tanah pada kedalaman berbeda di tambak Provinsi Sulawesi Selatan, Indonesia

Table 1. Descriptive statistics of soil quality chemical variables in different depths in brackishwater ponds of South Sulawesi Province, Indonesia

\begin{tabular}{|c|c|c|}
\hline \multirow{2}{*}{$\begin{array}{c}\text { Peubah } \\
\text { Variables }\end{array}$} & \multicolumn{2}{|c|}{ Kedalaman (Depths) (m) } \\
\hline & $0-0.2$ & $0.2-0.5$ \\
\hline $\mathrm{pH}_{\mathrm{F}}$ & $6.90 \pm 0.51^{b}$ & $6.79 \pm 0.47^{\mathrm{a}}$ \\
\hline $\mathrm{pH}_{\mathrm{FOX}}$ & $3.28 \pm 2.06^{b}$ & $2.92 \pm 2.08^{\mathrm{a}}$ \\
\hline $\mathrm{pH}_{\mathrm{F}}-\mathrm{pH}_{\mathrm{FOX}}$ & $3.62 \pm 2.08^{\mathrm{a}}$ & $3.89 \pm 2.06^{\mathrm{b}}$ \\
\hline $\mathrm{pH}_{\mathrm{KCl}}$ & $6.41 \pm 1.25^{b}$ & $5.77 \pm 1.59^{\mathrm{a}}$ \\
\hline $\mathrm{pH}_{\mathrm{OX}}$ & $3.47 \pm 2.10^{\mathrm{b}}$ & $3.13 \pm 2.20^{\mathrm{a}}$ \\
\hline $\mathrm{S}_{\mathrm{KCl}}(\%)$ & $0.5035 \pm 0.4329^{\mathrm{a}}$ & $0.5276 \pm 0.4698^{\mathrm{a}}$ \\
\hline $\mathrm{S}_{\mathrm{P}}(\%)$ & $3.3730 \pm 4.8084^{\mathrm{a}}$ & $3.2679 \pm 4.8084^{\mathrm{a}}$ \\
\hline $\mathrm{S}_{\mathrm{POS}}(\%)$ & $2.8446 \pm 4.5590^{\mathrm{a}}$ & $2.7919 \pm 4.7000^{\mathrm{a}}$ \\
\hline $\mathrm{TPA}\left(\mathrm{mol} \mathrm{H}^{+} / \mathrm{t}\right)\left(\right.$ mole $\left.H^{+} / t\right)$ & $305.8559 \pm 387.1662^{\mathrm{a}}$ & $401.8283 \pm 469.8876^{b}$ \\
\hline $\mathrm{TAA}\left(\mathrm{mol} \mathrm{H}^{+} / \mathrm{t}\right)\left(\right.$ mole $\left.^{+} / t\right)$ & $2.0911 \pm 7.1338^{\mathrm{a}}$ & $4.3511 \pm 9.8679^{\mathrm{b}}$ \\
\hline $\mathrm{TSA}\left(\mathrm{mol} \mathrm{H}^{+} / \mathrm{t}\right)\left(\right.$ mole $\left.H^{+} / t\right)$ & $297.6755 \pm 377.8816^{a}$ & $393.6689 \pm 461.3460^{\mathrm{b}}$ \\
\hline Pirit (Pyrite ) $(\%)$ & $1.3713 \pm 1.7566^{\mathrm{a}}$ & $1.7846 \pm 2.1015^{\mathrm{b}}$ \\
\hline $\mathrm{Fe}(\mathrm{mg} / \mathrm{L})$ & $2,310.86 \pm 2,147.71^{\mathrm{a}}$ & $2,440.68 \pm 2,219.88^{a}$ \\
\hline $\mathrm{Al}(\mathrm{mg} / \mathrm{L})$ & $230.79 \pm 216.97^{\mathrm{a}}$ & $257.40 \pm 243.28^{\mathrm{b}}$ \\
\hline C organik (Organic C) $(\%)$ & $4.7093 \pm 4.3588^{\mathrm{a}}$ & $5.6606 \pm 4.7910^{\mathrm{b}}$ \\
\hline $\mathrm{N}$ total $($ Total $N)(\%)$ & $0.3327 \pm 0.2725^{\mathrm{b}}$ & $0.2987 \pm 0.2480^{\mathrm{a}}$ \\
\hline Rasio C:N (C:N ratio ) & $14.88 \pm 12.06^{\mathrm{a}}$ & $18.62 \pm 14.24^{\mathrm{b}}$ \\
\hline $\mathrm{PO}_{4}(\mathrm{mg} / \mathrm{L})$ & $57.2864 \pm 88.1426^{\mathrm{b}}$ & $39.3109 \pm 55.8795^{\mathrm{a}}$ \\
\hline
\end{tabular}

Angka rata-rata dan deviasi standar yang diikuti huruf yang sama pada baris yang sama menunjukkan berbeda tidak nyata $(\mathrm{P}>0,05)$

(Average value and standard deviation followed by the same letter in the same row indicate is not significantly different $(P>0.05))$

Konsentrasi Fe tanah tambak pada kedalaman 0$0,2 \mathrm{~m}$ lebih rendah, tetapi berbeda tidak nyata $(\mathrm{P}>0,05)$ dibandingkan kedalaman 0,2-0,5 m. Konsentrasi Fe tanah tambak pada kedalaman 0-0,2 $\mathrm{m}$ yang tergolong kategori sedang adalah 83,50 $4.580,60 \mathrm{mg} / \mathrm{L}$. Kategori sedang yang dilaporkan Boyd et al. (1994) untuk Fe dari tanah tambak Thailand, Filipina, Ekuador, dan Venezuela sebesar 200-750 mg/ L. Kisaran yang lebar dari konsentrasi Fe kategori sedang dari tambak Sulawesi Selatan diduga sebagai akibat konsentrasi Fe yang rendah pada tanah nonsulfat masam dan konsentrasi Fe yang tinggi pada tanah sulfat masam dan tanah gambut.

Konsentrasi Al tanah tambak pada kedalaman 0$0,2 \mathrm{~m}$ lebih rendah dan berbeda nyata $(\mathrm{P}<0,05)$ dibandingkan kedalaman 0,2-0,5 m. Lebih rendahnya konsentrasi unsur toksin ( $\mathrm{Fe}, \mathrm{Al}$ ) pada permukaan tanah sebagai akibat proses remediasi secara alami dalam waktu yang cukup lama yang membuang unsur toksin tersebut dari permukaan tanah. Telah dilaporkan oleh
Vuai et al. (2003) bahwa air aliran permukaan dari tanah sulfat masam didominasi oleh $\mathrm{Fe}, \mathrm{Al}$, dan $\mathrm{SO}_{4}$. Hal ini menunjukkan bahwa $\mathrm{Fe}, \mathrm{Al}$, dan $\mathrm{SO}_{4}$ yang larut dalam air dan selanjutnya ikut bersama air permukaan tanah sulfat masam yang menyebabkan berkurangnya unsur atau senyawa tersebut pada permukaan tanah. Penyebab lainnya diduga karena kedua unsur toksin tersebut dinetralisir oleh kapur yang diberikan oleh pembudidaya tambak. Konsentrasi Al sebesar 81,00$317,60 \mathrm{mg} / \mathrm{L}$ tergolong kategori sedang di tanah tambak Sulawesi Selatan pada kedalaman 0-0,2 m. Di tanah tambak Thailand, Filipina, Ekuador, dan Venezuela, konsentrasi $\mathrm{Al}$ yang termasuk kategori sedang adalah $200-500 \mathrm{mg} / \mathrm{L}$ (Boyd et al., 1994).

$\mathrm{C}$ organik merupakan sumber energi bagi bakteri atau mikroba lainnya yang dapat menghasilkan nutrien melalui berbagai proses biokimia. Konsentrasi $\mathrm{C}$ organik pada kedalaman 0-0,2 m lebih rendah dan berbeda nyata $(\mathrm{P}<0,05)$ dengan kedalaman $0,2-0,5 \mathrm{~m}$. Konsentrasi $\mathrm{C}$ organik tanah tambak pada kedalaman 
Tabel 2. Kategori konsentrasi berbagai peubah kimia kualitas tanah pada kedalaman 0-0,2 m di tambak Provinsi Sulawesi Selatan, Indonesia

Table 2. Concentration category of various soil quality chemical variables in depth 0-0.2 $\mathrm{m}$ in brackishwater ponds of South Sulawesi Province, Indonesia

\begin{tabular}{|c|c|c|c|c|c|}
\hline \multirow{3}{*}{$\begin{array}{c}\text { Peubah } \\
\text { Variables }\end{array}$} & \multicolumn{5}{|c|}{ Desil (Decile) } \\
\hline & $\begin{array}{l}\text { Ke-1 } \\
1^{\text {st }}\end{array}$ & $\begin{array}{l}\text { Ke-2 dan ke-3 } \\
2^{\text {nd }} \text { and } 3^{\text {rd }}\end{array}$ & $\begin{array}{c}\text { Ke-4 sampai ke-7 } \\
4^{\text {th }} \text { to } 7^{\text {th }}\end{array}$ & $\begin{array}{l}\text { Ke-8 dan ke-9 } \\
8^{\text {th }} \text { and } 9^{\text {th }}\end{array}$ & $\begin{array}{l}\text { Ke-10 } \\
10^{\text {th }}\end{array}$ \\
\hline & $\begin{array}{l}\text { Sangat } \\
\text { rendah } \\
\text { Very low }\end{array}$ & $\begin{array}{l}\text { Rendah } \\
\text { Low }\end{array}$ & $\begin{array}{l}\text { Sedang } \\
\text { Medium }\end{array}$ & $\begin{array}{l}\text { Tinggi } \\
\text { High }\end{array}$ & $\begin{array}{c}\text { Sangat } \\
\text { tinggi } \\
\text { Very high }\end{array}$ \\
\hline $\mathrm{pH}_{\mathrm{F}}$ & $<6.30$ & $6.30-<6.70$ & $6.70-7.20$ & $>7.20-7.45$ & $>7.45$ \\
\hline $\mathrm{pH}_{\mathrm{FOX}}$ & $<0.90$ & $0.90-<1.65$ & $1.65-4.80$ & $>4.80-6.30$ & $>6.30$ \\
\hline $\mathrm{pH}_{\mathrm{F}}-\mathrm{pH}_{\mathrm{FOX}}$ & $<0.60$ & $0.60-<2.10$ & $2.10-5.25$ & $>5.25-6.05$ & $>6.05$ \\
\hline $\mathrm{pH}_{\mathrm{KCl}}$ & $<4.45$ & $4.45-<6.10$ & $6.10-7.20$ & $>7.20-7.70$ & $>7.70$ \\
\hline $\mathrm{pH}_{\mathrm{OX}}$ & $<1.30$ & $1.30-1.90$ & $1.90-4.35$ & $>4.35-6.80$ & $>6.80$ \\
\hline $\mathrm{S}_{\mathrm{KCl}}(\%)$ & $<0.1060$ & $0.1060-<0.2345$ & $0.2345-0.6165$ & $>0.6165-1.0350$ & $>1.0350$ \\
\hline$S_{P}(\%)$ & $<0.2895$ & $0.2895-<0.8595$ & $0.8595-2.9045$ & $>2.9045-9.7940$ & $>9.7940$ \\
\hline $\mathrm{S}_{\mathrm{POS}}(\%)$ & $<0.1065$ & $0.1065-<0.4805$ & $0.4805-2.2825$ & $>2.2825-8.7275$ & $>8.7275$ \\
\hline $\operatorname{TPA}\left(\mathrm{mol} \mathrm{H}^{+} / \mathrm{t}\right)\left(\right.$ mole $\left.H^{+} / t\right)$ & $<0.10$ & $0.10-<17.00$ & $17.00-392.90$ & $>392.90-850.00$ & $>850.00$ \\
\hline $\mathrm{TAA}\left(\mathrm{mol} \mathrm{H}^{+} / \mathrm{t}\right)\left(\right.$ mole $\left.^{+} / t\right)$ & $<0.05$ & $0.05-<0.10$ & $0.10-3.00$ & $>3.00-4.60$ & $>4.60$ \\
\hline $\mathrm{TSA}\left(\mathrm{mol} \mathrm{H}^{+} / \mathrm{t}\right)\left(\right.$ mole $\left.^{+} / t\right)$ & $<0.05$ & $0.05-<15.00$ & $15.00-384.25$ & $>384.25-826.00$ & $>826.00$ \\
\hline Pirit (Pyrite) $(\%)$ & $<0.0005$ & $0.0005-<0.0670$ & $0.0670-1.7590$ & $>1.7590-3.7945$ & $>3.7945$ \\
\hline $\mathrm{Fe}(\mathrm{mg} / \mathrm{L})$ & $<0.50$ & $0.50-<83.50$ & $83.50-4,580.60$ & $>4,580.60-4,902.00$ & $>4,902.00$ \\
\hline $\mathrm{Al}(\mathrm{mg} / \mathrm{L})$ & $<0.50$ & $0.50-<81.00$ & $81.00-317.60$ & $>317.60-501.10$ & $>501.10$ \\
\hline C organik (Organic C) (\%) & $<0.7120$ & $0.7120-<1.6855$ & $1.6855-5.6050$ & $>5.6050-11.3185$ & $>11.3185$ \\
\hline $\mathrm{N}$ total $($ Total $N)(\%)$ & $<0.0800$ & $0.0800-<0.1665$ & $0.1665-0.3850$ & $>0.3850-0.6875$ & $>0.6875$ \\
\hline Rasio C:N (C:N ratio ) & $<4.20$ & $4.20-<8.35$ & $8.35-16.70$ & $>16.70-27.35$ & $>27.35$ \\
\hline $\mathrm{PO}_{4}(\mathrm{mg} / \mathrm{L})$ & $<1.0040$ & $1.0040-<13.2845$ & $13.2845-67.3450$ & $>67.3450-143.3495$ & $>143.3495$ \\
\hline
\end{tabular}

0-0,2 m yang tergolong sedang adalah 1,6855\%$5,6050 \%$. Konsentrasi $C$ organik kategori sedang ini tergolong lebih tinggi jika dibandingkan dengan yang dilaporkan oleh Boyd et al. (1994) yang mendapatkan kategori sedang sebesar 1,0\%-2,5\% pada tanah tambak Thailand, Filipina, Ekuador, dan Venezuela. Konsentrasi $\mathrm{C}$ organik kategori sedang ini juga tergolong lebih tinggi jika dibandingkan dengan kategori sedang sebesar 2,0\%-3,0\% untuk tanah pertanian di Indonesia (Pusat Penelitian Tanah, 1993 dalam Hardjowigeno \& Widiatmaka, 2011). Konsentrasi $C$ organik sebesar 1,00\%-1,80\% dikategorikan sedang dalam hubungannya dengan kesuburan fisika tanah oleh Charman \& Roper (2007) dan sebesar 1,00\%-1,59\% juga dikategorikan sedang dalam hubungannya dengan penilaian kondisi tanah oleh Hazelton \& Murphy (2009). Lebih tingginya konsentrasi $\mathrm{C}$ organik pada lokasi studi ini sebagai akibat tanah tambak di pantai Timur Sulawesi Selatan tergolong tanah sulfat masam yang berasosiasi dengan tanah gambut. Dalam sistem klasifikasi taksonomi tanah, tanah gambut disebut Histosols, dan didefinisikan secara kualitatif atau terukur, mengikuti definisi ini, maka histosols harus terdiri atas bahan tanah organik yaitu: konsentrasi $\mathrm{C}$ organik minimal $12 \%$, apabila tidak mengandung fraksi liat $(0 \%)$ atau konsentrasi C organik minimal $18 \%$, apabila mengandung fraksi liat $60 \%$ atau lebih, atau jika mengandung fraksi liat antara $0 \%-60 \%$, maka konsentrasi $C$ organik adalah $12 \%+(\%$ konsentrasi liat dikalikan 0,1) (Subagyo, 2006).

Bahan organik, selain menghasilkan $\mathrm{C}$, juga menghasilkan nutrien atau unsur hara seperti $\mathrm{N}$. N total menggambarkan jumlah $\mathrm{N}$ yang ada dalam tanah, kebanyakan berada dalam bahan organik dan tidak secepatnya tersedia untuk tanaman ataupun alga. Dari Tabel 1 terlihat bahwa konsentrasi $\mathrm{N}$ total pada kedalaman 0-0,2 $\mathrm{m}$ lebih tinggi dan berbeda nyata $(\mathrm{P}<0,05)$ dengan kedalaman 0,2-0,5 $\mathrm{m}$. Tingginya 
Tabel 3. Kategori konsentrasi berbagai peubah kimia kualitas tanah pada kedalaman 0,2-0,5 m di tambak Provinsi Sulawesi Selatan, Indonesia

Table 3. Concentration category of various soil quality chemical variables in depth 0.2-0.5 $\mathrm{m}$ in brackishwater ponds of South Sulawesi Province, Indonesia

\begin{tabular}{|c|c|c|c|c|c|}
\hline \multirow{3}{*}{$\begin{array}{l}\text { Peubah } \\
\text { Variables }\end{array}$} & \multicolumn{5}{|c|}{ Desil (Decile) } \\
\hline & $\begin{array}{l}\text { Ke-1 } \\
1^{\text {st }}\end{array}$ & $\begin{array}{l}\text { Ke-2 dan ke-3 } \\
2^{\text {nd }} \text { and } 3^{r d}\end{array}$ & $\begin{array}{c}\text { Ke-4 sampai ke-7 } \\
4^{\text {th }} \text { to } 7^{\text {th }}\end{array}$ & $\begin{array}{l}\text { Ke-8 dan ke-9 } \\
8^{\text {th }} \text { and } 9^{\text {th }}\end{array}$ & $\begin{array}{l}\mathrm{Ke}-10 \\
10^{t h}\end{array}$ \\
\hline & $\begin{array}{l}\text { Sangat } \\
\text { rendah } \\
\text { Very low }\end{array}$ & $\begin{array}{l}\text { Rendah } \\
\text { Low }\end{array}$ & $\begin{array}{l}\text { Sedang } \\
\text { Medium }\end{array}$ & $\begin{array}{l}\text { Tinggi } \\
\text { High }\end{array}$ & $\begin{array}{c}\text { Sangat } \\
\text { tinggi } \\
\text { Very high }\end{array}$ \\
\hline $\mathrm{pH}_{\mathrm{F}}$ & $<6.30$ & $6.30-<6.65$ & $6.65-7.00$ & $>7.00-7.25$ & $>7.25$ \\
\hline $\mathrm{pH}_{\mathrm{FOX}}$ & $<0.85$ & $0.85-<1.40$ & $1.40-4.25$ & $>4.25-6.15$ & $>6.15$ \\
\hline $\mathrm{pH}_{\mathrm{F}}-\mathrm{pH}_{\mathrm{FOX}}$ & $<0.75$ & $0.75-<2.25$ & $2.25-5.45$ & $>5.45-6.00$ & $>6.00$ \\
\hline $\mathrm{pH}_{\mathrm{KCl}}$ & $<3.40$ & $3.40-<4.95$ & $4.95-6.85$ & $>6.85-7.50$ & $>7.50$ \\
\hline $\mathrm{pH}_{\mathrm{OX}}$ & $<1.00$ & $1.00-<1.50$ & $1.50-4.10$ & $>4.10-6.65$ & $>6.65$ \\
\hline $\mathrm{S}_{\mathrm{KCl}}(\%)$ & $<0.0720$ & $0.0720-<0.2125$ & $0.2125-0.6485$ & $>0.6485-1.2310$ & $>1.2310$ \\
\hline $\mathrm{S}_{\mathrm{P}}(\%)$ & $<0.2895$ & $0.2895-<0.8595$ & $0.8595-2.9045$ & $>2.9045-9.7940$ & $>9.7940$ \\
\hline $\mathrm{S}_{\mathrm{POS}}(\%)$ & $<0.0575$ & $0.0575-<0.5285$ & $0.5285-2.3150$ & $>2.3150-7.0025$ & $>7.0025$ \\
\hline $\mathrm{TPA}\left(\mathrm{mol} \mathrm{H}^{+} / \mathrm{t}\right)\left(\right.$ mole $\left.H^{+} / t\right)$ & $<0.10$ & $0.10-<29.50$ & $29.50-542.80$ & $>542.80-1,131.00$ & $>1,131.00$ \\
\hline $\mathrm{TAA}\left(\mathrm{mol} \mathrm{H}^{+} / \mathrm{t}\right)\left(\right.$ mole $\left.H^{+} / t\right)$ & $<0.05$ & $0.05-<0.10$ & $0.10-5.00$ & $>5.00-18.20$ & $>18.20$ \\
\hline $\mathrm{TSA}\left(\mathrm{mol} \mathrm{H}^{+} / \mathrm{t}\right)\left(\right.$ mole $\left.H^{+} / t\right)$ & $<0.05$ & $0.05-<28.30$ & $28.30-529.00$ & $>529.00-1,083.60$ & $>1,083.60$ \\
\hline Pirit (Pyrite) $(\%)$ & $<0.0005$ & $0.0005-<0.1315$ & $0.1315-2.3770$ & $>2.3770-4.8855$ & $>4.8855$ \\
\hline $\mathrm{Fe}(\mathrm{mg} / \mathrm{L})$ & $<0.50$ & $0.50-<45.50$ & $45.50-4,572.20$ & $>4,572.20-4,939.65$ & $>4,939.65$ \\
\hline $\mathrm{Al}(\mathrm{mg} / \mathrm{L})$ & $<0.50$ & $0.50-<77.20$ & $77.20-337.40$ & $>337.40-575.00$ & $>575.00$ \\
\hline C organik (Organic C) $(\%)$ & $<0.5615$ & $0.5615-<2.2175$ & $2.2175-7.1150$ & $>7.1150-13.1815$ & $>13.1815$ \\
\hline $\mathrm{N}$ total $($ Total $N)(\%)$ & $<0.0715$ & $0.0715-<0.1510$ & $0.1510-0.3390$ & $>0.3390-0.6280$ & $>0.6280$ \\
\hline Rasio C:N (C:N ratio ) & $<4.10$ & $4.10-<11.10$ & $11.10-21.15$ & $>21.15-35.40$ & $>35.40$ \\
\hline $\mathrm{PO}_{4}(\mathrm{mg} / \mathrm{L})$ & $<1.0000$ & $1.0000-<8.7225$ & $8.7225-39.6320$ & $>39.6320-101.4260$ & $>101.4260$ \\
\hline
\end{tabular}

konsentrasi $\mathrm{N}$ total pada kedalaman 0-0,2 m sebagai akibat penambahan pupuk yang mengandung $\mathrm{N}$ seperti urea yang diaplikasikan oleh pembudidaya tambak, baik sebagai pupuk dasar maupun sebagai pupuk susulan. Konsentrasi $\mathrm{N}$ total tanah pada berbagai kategori untuk kedalaman 0-0,2 m dan 0,2-0,5 m di tambak Sulawesi Selatan disajikan pada Tabel 2 dan 3. Konsentrasi ini relatif tidak berbeda jika dibandingkan dengan yang telah dilaporkan sebelumnya. Boyd et al. (1994) mendapatkan konsentrasi $\mathrm{N}$ total yang tergolong kategori sangat rendah, rendah, sedang, tinggi, dan sangat tinggi di tanah tambak Thailand, Filipina, Ekuador, dan Venezuela adalah berturut-turut $<0,15 \%$; 0,15\%-0,25\%; 0,25\%-0,40\%; 0,40\%-0,50\%; dan > 0,50\%. Pusat Penelitian Tanah (1993) dalam Hardjowigeno \& Widiatmaka (2011) mendapatkan konsentrasi $<0,10 \%$; $0,10 \%-0,20 \%$; 0,20\%-0,50\%; 0,50\%-0,75\%; dan >0,75\% adalah konsentrasi $\mathrm{N}$ total yang berturut-turut tergolong kategori sangat rendah, rendah, sedang, tinggi, dan sangat tinggi di tanah pertanian Indonesia. Konsentrasi $N$ total tanah $<0,05 \%$; 0,05\%-0,15\%; $0,15 \%-0,25 \% ; 0,25 \%-0,50 \%$; dan $>0,50 \%$ dikategorikan berturut-turut sangat rendah, rendah, sedang, tinggi, dan sangat tinggi oleh Bruce \& Rayment (1982).

Rasio C:N tanah berpengaruh terhadap aktivitas mikroba tanah dalam kecepatan proses mineralisasi bahan organik untuk menghasilkan unsur hara. Sebagai akibat konsentrasi $\mathrm{C}$ organik yang lebih rendah dan konsentrasi $\mathrm{N}$ total yang lebih tinggi pada kedalaman 0-0,2 m menyebabkan rasio $\mathrm{C}: \mathrm{N}$ tanah lebih rendah dan berbeda nyata $(\mathrm{P}<0,05)$ dengan kedalaman 0,2 $0,5 \mathrm{~m}$. Rasio C:N yang lebih rendah pada lapisan atas (25) dibandingkan dengan lapisan bawah (39) dilaporkan oleh Subagyo (2006) pada tanah sulfat masam aktual di Kalimantan. Rasio C:N tanah sebesar 8,35-16,70 adalah tergolong kategori sedang di tanah tambak Sulawesi Selatan. Rasio C:N sebesar 11-15 tergolong kategori sedang pada tanah pertanian di 
Indonesia (Pusat Penelitian Tanah, 1993 dalam Hardjowigeno \& Widiatmaka, 2011). Rasio C:N tanah sebesar 15-25 digolongkan kategori sedang dan pada rasio ini menunjukkan proses dekomposisi bahan organik yang lambat (Hazelton \& Murphy, 2009).

Selain N, maka P adalah unsur hara makro yang sangat dibutuhkan oleh makanan alami di tambak yang merupakan makanan utama bagi komoditas air payau terutama yang dikelola secara tradisional. P adalah suatu unsur hara esensial yang mempunyai peran besar dalam reaksi biokimia termasuk fotosintesis dan respirasi. Konsentrasi $\mathrm{PO}_{4}$ tanah pada kedalaman 0$0,2 \mathrm{~m}$ lebih tinggi dan berbeda nyata $(\mathrm{P}<0,05)$ dengan kedalaman 0,2-0,5 m. Hal ini juga sebagai akibat penambahan pupuk yang mengandung $\mathrm{PO}_{4}$ seperti SP36 pada permukaan tanah sebagai pupuk dasar dan pada badan air yang akhirnya mengendap di permukaan tanah sebagai pupuk susulan pada saat pelaksanaan budidaya tambak. Penyebab lain lebih tingginya konsentrasi $\mathrm{PO}_{4}$ pada kedalaman 0-0,2 m sebagai akibat lebih rendahnya konsentrasi Fe dan Al. Pada tanah dengan $\mathrm{pH}$ sangat rendah seperti pada tanah sulfat masam, $\mathrm{P}$ sangat kuat diikat oleh Fe dan $\mathrm{Al}$ masingmasing dalam bentuk $\mathrm{FePO}_{4}$ dan $\mathrm{AlPO}_{4}$ yang merupakan bentuk yang tidak tersedia (Mustafa \& Sammut, 2007; Hazelton \& Murphy, 2009). Hasil yang relatif sama telah dilaporkan oleh Subagyo (2006) bahwa konsentrasi Ptersedia $\left(\mathrm{P}_{2} \mathrm{O}_{5}\right.$-Bray 1) lebih tinggi pada lapisan atas (19,3 mg/L) daripada lapisan bawah $(12,6 \mathrm{mg} / \mathrm{L})$ pada tanah sulfat masam aktual di Kalimantan. Konsentrasi $\mathrm{PO}_{4}$ 13,2845-67,3450 mg/L tergolong kategori sedang pada kedalaman 0-0,2 m di tanah tambak Sulawesi Selatan. Konsentrasi $\mathrm{PO}_{4}$-Bray 1 sebesar 21,4-33,5 mg/ $\mathrm{L}$ dan $\mathrm{PO}_{4}$-Olsen sebesar 15,5-30,5 mg/L dikategorikan sedang oleh Pusat Penelitian Tanah (1993) dalam Hardjowigeno \& Widiatmaka (2011) untuk tanah pertanian Indonesia.

Tambak yang dijadikan objek dalam studi ini adalah tambak yang sebagian besar digunakan untuk produksi udang windu, ikan bandeng, ikan nila, dan rumput laut, baik secara monokultur ataupun polikultur. Akan tetapi, sangat sedikit data produksi tambak yang diperoleh, sehingga tidak mungkin untuk membuat penilaian konsentrasi optimum setiap peubah kimia kualitas tanah dari data yang disajikan dalam studi ini. Data yang disajikan ini menunjukkan bahwa setiap peubah kimia kualitas tanah menunjukkan kisaran nilai yang sangat besar, namun masih memungkinkan untuk budidaya udang, ikan, dan rumput laut yang kisaran produksinya juga besar. Hasil studi yang diperoleh ini tidak disarankan untuk digunakan dalam menentukan hubungan antara kualitas tanah dan produktivitas tambak, sebab secara umum konsentrasi setiap unsur atau senyawa dalam tanah yang dibutuhkan untuk produksi tambak yang optimal bukan pada konsentrasi yang sangat tinggi atau sangat rendah, tetapi pada konsentrasi tertentu. Namun demikian, kriteria konsentrasi ini dapat menjadi dasar dalam penilaian cepat untuk menentukan peubah kimia kualitas tanah tambak termasuk kategori sangat rendah, rendah, sedang, tinggi, atau sangat tinggi dan membuat keputusan untuk perbaikan kualitas tanah.

\section{KESIMPULAN DAN SARAN}

Hasil studi menunjukkan bahwa secara umum tanah tambak di Sulawesi Selatan, Indonesia pada kedalaman tanah 0-0,2 m memiliki kemasaman dan konsentrasi unsur toksin (Fe, $\mathrm{Al}$ ) yang lebih rendah dan sebaliknya konsentrasi unsur hara makro $(\mathrm{N}, \mathrm{P})$ yang lebih tinggi dibandingkan pada kedalaman 0,2-0,5 m. Peubah kimia kualitas tanah lainnya seperti $\mathrm{S}_{\mathrm{KCl}}, \mathrm{S}_{\mathrm{P}}$, dan $\mathrm{S}_{\mathrm{POS}}$ relatif sama konsentrasinya pada kedua kedalaman. Data setiap peubah kimia kualitas tanah telah disusun ke dalam kategori konsentrasi (sangat rendah, rendah, sedang, tinggi, sangat tinggi) untuk memfasilitasi perbandingan dengan data lain mengenai kualitas tanah untuk budidaya tambak. Hasil studi yang diperoleh ini tidak disarankan untuk digunakan dalam menentukan hubungan antara kualitas tanah dan produktivitas tambak, tetapi dapat menjadi dasar dalam menentukan peubah kimia kualitas tanah tambak termasuk kategori sangat rendah, rendah, sedang, tinggi, atau sangat tinggi dan membuat keputusan untuk perbaikan kualitas tanah.

\section{UCAPAN TERIMA KASIH}

Ucapan terima kasih disampaikan kepada Muhammad Arnol, Ilham, Darsono, dan Hakim Madeng atas bantuannya dalam pengambilan contoh tanah di lapangan dan penyiapan contoh tanah untuk dianalisis di laboratorium. Ucapan terima kasih juga diucapkan kepada Rosiana Sabang, Kamariah, dan Rahmiyah atas bantuannya dalam analisis tanah di laboratorium. Kepada ACIAR (Australian Centre for International Agricultural Research) PROJECT FIS/1997/022 (Remediation and Management of Degraded Earthen Shrimp Ponds in Indonesia) untuk lokasi Kabupaten Barru, Sinjai, Wajo, dan Luwu dan ACIAR PROJECT FIS/ 2007/124 (Diversification of Smallholder Coastal Aquaculture in Indonesia) untuk lokasi Kabupaten Pangkep, Maros, dan Takalar juga diucapkan terima kasih atas biaya studi ini.

\section{DAFTAR ACUAN}

Ahern, C.R., \& Blunden, B. (1998). Designing a soil sampling and analysis program. In: Ahern, C.R., Blunden, B., \& Stone, Y. (Eds.). Acid sulfate soils laboratory methods guidelines. Acid Sulfate Soil 
Management Advisory Committee. Wollongbar, p. 2.1-2.6.

Ahern, C.R., \& Rayment, G.E. (1998). Codes for acid sulfate soils analytical methods. In: Ahern, C.R., Blunden, B., \& Stone, Y. (Eds.). Acid sulfate soils laboratory methods guidelines. Acid Sulfate Soil Management Advisory Committee. Wollongbar, p. 3.1-3.5.

Ahern, C.R., McElnea, A., \& Baker, D.E. (1998a). Acid neutralizing capacity methods. In: Ahern, C.R., Blunden, B., \& Stone, Y. (Eds.). Acid sulfate soils laboratory methods guidelines. Acid Sulfate Soil Management Advisory Committee. Wollongbar, p. 6.1-6.4.

Ahern, C.R., McElnea, A., \& Baker, D.E. (1998b). Peroxide oxidation combined acidity and sulfate. In: Ahern, C.R., Blunden, B., \& Stone, Y. (Eds.). Acid sulfate soils laboratory methods guidelines. Acid Sulfate Soil Management Advisory Committee. Wollongbar, p. 4.1-4.17.

Ahern, C.R., Blunden, B., Sullivan, L.A., \& McElnea, A.E. (2004). Soil sampling, handling, preparation and storage for analysis of dried samples. In: Acid sulfate soils laboratory methods guidelines. Queensland Department of Natural Resources, Mines and Energy. Indooroopilly, p. B1-1-B1-5.

Ahern, C.R., \& McElnea, A. (2004). Calculated sulfur parameters. In: Acid sulfate soils laboratory methods guidelines. Queensland Department of Natural Resources, Mines and Energy. Indooroopilly, p. B11-1-B11-2.

Ahmed, H. (2004). Soil quality analysis and considerations in the selection of sites for sustainable aquaculture in the south east coast of chittagong specially halishahar area. Master of Science Thesis. Institute of Marine Sciences and Fisheries, University of Chittagong. Chittagong, 80 pp.

Avnimelech, Y., \& Ritvo, G. (2003). Shrimp and fish pond soils: processes and management. Aquaculture, 220, 549-567.

Boyd, C.E. (1976). Chemical and textural properties of muds from different depths in ponds. Hydrobiologia, 48, 141-144.

Boyd, C.E. (1989). Water quality management and aeration in shrimp farming. Fisheries and Allied Aquacultures Department Seri No. 2. Alabama Agricultural Experiment Station, Auburn University. Auburn, 83 pp.

Boyd, C.E. (1992). Shrimp pond bottom soil and sediment management. In: Wyban, J. (Ed.). Proceedings of the Special Session on Shrimp Farming. World Aquaculture Society. Baton Rouge, p. 166-181.

Boyd, C.E., Tanner, M.E., Madkour, M., \& Masuda, K. (1994). Chemical characteristics of bottom soils from freshwater and brackishwater aquaculture ponds. Journal of the World Aquaculture Society, 25(4), 517-534.

Boyd, C.E. (1995). Bottom soils, sediment, and pond aquaculture. Chapman and Hall. New York, 348 pp.

Bruce, R.C., \& Rayment, G.E. (1982). Analytical methods and interpretations used by the agricultural chemistry branch for soil and land use surveys. Queensland Department of Primary Industries. Brisbane, $10 \mathrm{pp}$.

Caipang, C.M.A., Fos, M.A., \& Golez, M.S.M. (2012). Bottom soil characteristics of brackishwater pond after a culture period. International Journal of the Bioflux Society, 5(5), 415-420.

Charman, P.E.V., \& Roper, M.M. (2007). Soil organic matter. In: Charman, P.E.V., \& Murphy, B.W. (Eds.). Soils - their properties and management. Third edition. Oxford University Press. Melbourne, p. 276285.

Conyers, M.K., Heenan, D.P., McGhie, W.J., \& Poile, G.P. (2003). Amelioration of acidity with time by limestone under contrasting tillage. Soil \& Tillage Research, 72, 85-94.

Dinas Kelautan dan Perikanan [DKP]. (2013). Laporan statistik perikanan Sulawesi Selatan 2012. Dinas Kelautan dan Perikanan Provinsi Sulawesi Selatan. Makassar, $166 \mathrm{hlm}$.

Ekubo, A.T., \& Abowei, J.F.N. (2011). A review fishpond soil management principles in Nigeria. Research Journal of Environmental and Earth Sciences, 3(6), 694-703.

English, S., Wilkinson, C., \& Basker, V. (1997). Survey manual for tropical marine resources. Second edition. Australian Institute of Marine Science. Townsville, p. 119-195.

Eviati \& Sulaeman. (2009). Analisis kimia tanah, tanaman, air, dan pupuk. Petunjuk Teknis Edisi 2. Balai Penelitian Tanah. Bogor, $234 \mathrm{hlm}$.

Giap, D.H., Yi, Y., \& Yakupitiyage, A. (2005). GIS for land evaluation for shrimp farming in Haiphong of Vietnam. Ocean \& Coastal Management, 48, 5163.

Hardjowigeno, S., \& Widiatmaka. (2011). Evaluasi kesesuaian lahan \& perencanaan tataguna lahan. Gadjah Mada University Press. Yogyakarta, 352 hlm.

Hasnawi \& Mustafa, A. (2010). Karakteristik, kesesuaian, dan pengelolaan lahan untuk budidaya tambak di Kabupaten Luwu Utara, Provinsi Sulawesi Selatan.J. Ris. Akuakultur, 5(3), 449-463.

Hazelton, P. \& Murphy, B. (2009). Interpreting soil test results: what do all the numbers mean? CSIRO Publishing. Collingwood, 152 pp. 
Karthik, M., Suri, J., Saharan, N., \& Biradar, R.S. (2005). Brackish water aquaculture site selection in Palghar Taluk, Thane district of Maharashtra, India, using the techniques of remote sensing and geographical information system. Aquacultural Engineering, 32, 285-302.

Kementerian Kelautan dan Perikanan [KKP]. (2014). Kelautan dan perikanan dalam angka tahun 2014. Kementerian Kelautan dan Perikanan. Jakarta, 302 hlm.

McElnea, A.E., \& Ahern, C.R. (2004a). KCl extractable $\mathrm{pH}\left(\mathrm{pH}_{\mathrm{KCI}}\right)$ and titratable actual acidity (TAA). In: Acid sulfate soils laboratory methods guidelines. Queensland Department of Natural Resources, Mines and Energy. Indooroopilly, p. B2-1-B2-3.

McElnea, A.E., \& Ahern, C.R. (2004b). Peroxide pH $\left(\mathrm{pH}_{\mathrm{Ox}}\right)$, titratable peroxide acidity (TPA) and excess acid neutralising capacity $\left(\mathrm{ANC}_{\mathrm{E}}\right)$. In: Acid sulfate soils laboratory methods guidelines. Queensland Department of Natural Resources, Mines and Energy. Indooroopilly, p. B3-1-B3-7.

McElnea, A.E., \& Ahern, C.R. (2004c). Sulfur-peroxide oxidation method. In: Acid sulfate soils laboratory methods guidelines. Queensland Department of Natural Resources, Mines and Energy. Indooroopilly, p. B7-1-B7-2.

McElnea, A.E., \& Ahern, C.R. (2004d). Sulfur 1M KCl extraction $\left(\mathrm{S}_{\mathrm{KCl}}\right)$. In: Acid sulfate soils laboratory methods guidelines. Queensland Department of Natural Resources, Mines and Energy. Indooroopilly, p. B8-1-B8-2.

Melville, M.D. (1993). Soil laboratory manual. School of Geography, The University of New South Wales. Sydney, 74 pp.

Menon, R.G. (1973). Soil and water analysis: a laboratory manual for the analysis of soil and water. Proyek Survey O.K.T. Sumatera Selatan. Palembang, 190 pp.

Mustafa, A. (2007). Improving acid sulfate soils for brackish water ponds in South Sulawesi, Indonesia. Doctor of Philosophy Thesis. The University of New South Wales. Sydney, 418 pp.

Mustafa, A., \& Ratnawati, E. (2007). Faktor-faktor dominan yang memengaruhi produktivitas tambak di Kabupaten Pinrang, Sulawesi Selatan. J. Ris. Akuakultur, 2(1), 117-133.

Mustafa, A., \& Sammut, J. (2007). Effect of different remediation techniques and dosages of phosphorus fertilizer on soil quality and klekap production in acid sulfate soil-affected aquaculture ponds. Indonesian Aquaculture Journal, 2(2), 141-157.

Mustafa, A., Rachmansyah, \& Hanafi, A. (2007). Kelayakan lahan untuk budi daya perikanan pesisir. Dalam: Susilo, D.S.I., Wiadnyana, N.N., Wijayanti,
E., Basmal, J., Asnawi, Supangat, A., Hanggono, A., \& Insan, I. (Eds.). Prosiding Simposium Nasional Hasil Riset Kelautan dan Perikanan Tahun 2007. Badan Riset Kelautan dan Perikanan. Jakarta, hlm. 141-157.

Mustafa, A., Hasnawi, Paena, M., Rachmansyah, \& Sammut, J. (2008a). Evaluasi kesesuaian lahan untuk budidaya tambak di Kabupaten Pinrang Provinsi Sulawesi Selatan.J. Ris. Akuakultur, 3(2), 241-261.

Mustafa, A., Paena, M., Tarunamulia, \& Sammut, J. (2008b). Hubungan antara faktor kondisi lingkungan dan produktivitas tambak untuk penajaman kriteria kesesuaian lahan. 2. Kualitas tanah. J. Ris. Akuakultur, 3(1), 105-121.

Mustafa, A. (2009). Hubungan antara faktor lingkungan dengan produksi udang vaname (Litopenaeus vannamei) di tambak Kabupaten Pesawaran Provinsi Lampung. Dalam: Sudradjat, A., Supriyadi, H., Hanafi, A., Kristanto, A.H., Chumaidi, Mustafa, A., Imron, \& Insan, I. (Eds.). Prosiding Forum Inovasi Teknologi Akuakultur 2009; Buku 1. Pusat Riset Perikanan Budidaya. Jakarta, hlm. 375-383.

Mustafa, A., \& Sammut, J. (2010). Dominant factors effecting seaweed (Gracilaria verrucosa) production in acid sulfate soils-affected ponds of Luwu Regency, Indonesia. Indonesian Aquaculture Journal, 5(2), 147-162.

Mustafa, A. (2010). Hubungan antara faktor lingkungan dengan produktivitas tambak untuk rumput laut (Gracilaria verrucosa) di pantai Timur Provinsi Sulawesi Selatan. Media Akuakultur, 5(1), 38-46.

Mustafa, A., Ratnawati, E., \& Utojo. (2010). Penentuan faktor pengelolaan tambak yang memengaruhi produktivitas tambak di Kabupaten Pangkep Provinsi Sulawesi Selatan. Dalam: Syamsuddin, S., Sipahutar, Y.H., Saifurridjal, Basith, A., Nurbani, S.Z., Suharto, Siregar, A.N., Rahardjo, S., Hadi, R.S., \& Sanova, V. (Eds.). Prosiding Seminar Nasional Perikanan 2010: Budidaya Perikanan. Sekolah Tinggi Perikanan. Jakarta, hlm. 320-329.

Mustafa, A., Radiarta, I N., \& Rachmansyah. (2011). Profil dan kesesuaian lahan akuakultur mendukung minapolitan. Diedit: Sudradjat, A. Pusat Penelitian dan Pengembangan Perikanan Budidaya. Jakarta, $91 \mathrm{hlm}$.

Mustafa, A. (2012). Kriteria kesesuaian lahan untuk berbagai komoditas di tambak. Media Akuakultur, 7(2), 108-118.

Mustafa, A., \& Ratnawati, E. (2012). Distribusi kebutuhan kapur berdasarkan nilai $S_{\text {POS }}$ tanah untuk tambak di Kabupaten Pangkep Provinsi Sulawesi Selatan. J. Ris. Akuakultur, 7(2), 293-306.

Mustafa, A., \& Ratnawati, E. (2013). Karakteristik dan pengaruh faktor lingkungan terhadap produksi ikan 
bandeng (Chanos chanos) di tambak tanah sulfat masam Kabupaten Konawe Selatan Provinsi Sulawesi Tenggara. J. Ris. Akuakultur, 8(2), 325-338.

Ndome, C.B., Udo, I.U., Akpan, I.I., \& Udom, C. (2012). Effect of water quality and bottom soil properties on the diversity and abundance of macrobenthic fauna in some tropical grow-out earthen fish ponds. Ecologia, 2(1), 12-22.

Noor, M. (2004). Lahan rawa: sifat dan pengelolaan tanah bermasalah sulfat masam. PT RajaGrafindo Persada. Jakarta, 238 hlm.

Queiroz, de J.F., Nicolella, G., Wood, C.W., \& Boyd, C.E. (2004). Lime application methods, water and bottom soil acidity in fresh water fish ponds. Scientia Agricola, 61(5), 469-475.

Rachmansyah, Mustafa, A., \& Paena, M. (2010). Karakteristik, kesesuaian, dan pengelolaan lahan tambak di Kota Pekalongan Provinsi Jawa Tengah. J. Ris. Akuakultur, 5(3), 505-521.

Rachmansyah, \& Mustafa, A. (2011a). Distribusi spasial karakteristik tanah tambak di Kabupaten Pangkep Provinsi Sulawesi Selatan. J. Ris. Akuakultur, 6(3), 479-493.

Rachmansyah, \& Mustafa, A. (2011b). Evaluasi kesesuaian lahan aktual tambak yang ada di Kabupaten Tanjung Jabung Barat Provinsi Jambi.J. Ris. Akuakultur, 6(2), 311-324.

Rachmansyah, Asaad, A.I.J., \& Mustafa, A. (2012). Karakteristik, kesesuaian, dan pengelolaan lahan tambak di Kecamatan Bulakamba Kabupaten Brebes Provinsi Jawa Tengah. J. Ris. Akuakultur, 7(2), 321335.

Ratnawati, E., Mustafa, A., \& Rachmansyah. (2008). Faktor status pembudidaya, kondisi dan pengelolaan tambak yang berpengaruh terhadap produksi rumput laut (Gracilaria verrucosa) di tambak tanah sulfat masam Kabupaten Luwu Utara Provinsi Sulawesi Selatan. J. Ris. Akuakultur, 3(2), 275-287.

Ratnawati, E., Mustafa, A., \& Utojo. (2009). Faktor pengelolaan yang memengaruhi produksi udang windu di tambak Kabupaten Bulukumba, Provinsi Sulawesi Selatan. Prosiding Seminar Nasional Perikanan 2009: Teknologi Penangkapan Ikan, Permesinan Perikanan, Teknologi Pengolahan Hasil Perikanan, Sosial Ekonomi Perikanan. Sekolah Tinggi Perikanan. Jakarta, hlm. 617-626.

Rayes, M.L. (2007). Metode inventarisasi sumber daya lahan. Penerbit Andi. Yogyakarta, 298 hlm.

Salam, M.A., Ross, L.G., \& Beveridge, C.M.M. (2003). A comparison of development opportunities for crab and shrimp aquaculture in Southwestern Bangladesh, using GIS modelling. Aquaculture, 220, 477-494.
Sammut, J. (1999). Amelioration and management of shrimp ponds in acid sulfate soils: key researchable issues. In: Smith, P.T. (Ed.). Towards sustainable shrimp culture in Thailand and the region. ACIAR Proceedings No. 90. Australian Centre for International Agricultural Research. Canberra, p. 102106.

Siddique, M.A.M., Barua, P., \& Ghani, M.H. (2012). Comparative study of physic-chemical properties of soil according to the age of aquaculture pond of Bangladesh. Mesopotamian Journal of Marine Science, 27(1), 29-38.

Subagyo, H. (2006). Lahan rawa pasang surut. Dalam: Ardi, S.D., Kurnia, U., Mamat, H.S., Hartatik, W., \& Setyorini, D. (Eds.). Karakteristik dan pengelolaan lahan rawa. Balai Besar Penelitian dan Pengembangan Sumberdaya Lahan Pertanian. Bogor, hlm. 23-98.

Sulaeman, Suparto, \& Eviati. (2005). Petunjuk teknis analisis kimia tanah, tanaman, air, dan pupuk. Diedit: Prasetyo, B.H., Santoso, D., \& Widowati, L.R. Balai Penelitian Tanah. Bogor, $136 \mathrm{hlm}$.

Tarunamulia, \& Mustafa, A. (2009). Evaluasi rinci karakteristik dan tingkat kesesuaian lahan tambak di Kecamatan Balusu Kabupaten Barru Provinsi Sulawesi Selatan. J. Ris. Akuakultur, 4(3), 425-438.

Utojo, Mustafa, A., Rachmansyah, \& Hasnawi. (2009a). Penentuan lokasi pengembangan budidaya tambak berkelanjutan dengan aplikasi sistem informasi geografis di Kabupaten Lampung Selatan. J. Ris. Akuakultur, 4(3), 407-423.

Utojo, Mustafa, A., Rachmansyah, \& Hasnawi. (2009b). Perencanaan kawasan pesisir di Kabupaten Bulukumba untuk lokasi pengembangan budidaya tambak ramah lingkungan. Dalam: Sudradjat, A., Supriyadi, H., Hanafi, A., Kristanto, A.H., Chumaidi, Mustafa, A., Imron, \& Insan, I. (Eds.). Prosiding Forum Inovasi Teknologi Akuakultur 2009; Buku 1. Pusat Riset Perikanan Budidaya. Jakarta, hlm. 423-437.

Utojo, Mustafa, A., \& Hasnawi. (2010). Model kesesuaian lokasi pengembangan budidaya tambak di kawasan pesisir Kabupaten Pontianak, Kalimantan Barat. J. Ris. Akuakultur, 5(3), 465-479.

Utojo, Mustafa, A., \& Hasnawi. (2011). Peruntukan kawasan pesisir Kabupaten Maros, Sulawesi Selatan sebagai lokasi pengembangan budidaya tambak ramah lingkungan. J. Ris. Akuakultur, 6(2), 325-339.

Utojo, Pirzan, A.M., \& Mustafa, A. (2012). Evaluasi kesesuaian lahan pesisir di Lamongan, Jawa Timur untuk pengembangan budidaya tambak dengan menelaah karakteristik, permasalahan, dan pengelolaan lahan. Dalam: Haryanti, Rachmansyah, 
Imron, Sunarto, A., Sugama, K., Sumiarsa, G.S., Parenrengi, A., Azwar, Z.I., Sudradjat, A., \& Kristanto, A.H. (Eds.). Prosiding Indoaqua - Forum Inovasi Teknologi Akuakultur 2012, Bidang Penyakit Ikan dan Lingkungan. Pusat Penelitian dan Pengembangan Perikanan Budidaya. Jakarta, hlm. 939-952.
Utojo, Hasnawi, \& Paena, M. (2013). Karakteristik, kesesuaian, dan pengelolaan lahan budidaya tambak di Kabupaten Gresik Provinsi Jawa Timur. J. Ris. Akuakultur, 8(2), 311-324.

Vuai, S.A., Nakamura, K., \& Tokuyama, A. (2003). Geochemical characteristics of runoff from acid sulfate soils in the northen area of Okinawa Island, Japan. Geochemical Journal, 37, 579-592. 
